\title{
Literature Review in Field of Factors Influencing the Attraction of FDI and Its Spillover Effects
}

\author{
Tsoneva Stefaniya Tsoneva ${ }^{1}$ \\ ${ }^{1}$ School of Economics, Shanghai University, Shanghai, China \\ Correspondence: Tsoneva Stefaniya Tsoneva, School of Economics, Shanghai University, Shanghai, China. \\ E-mail: stefaniya.tsoneva@yahoo.com
}

Received: January 10, 2021

Accepted: March 31, 2021

Online Published: April 10, 2021

doi:10.5539/ijef.v13n5p56

URL: https://doi.org/10.5539/ijef.v13n5p56

\begin{abstract}
The study of FDI and its identification as a specific type of investment activity began in the 60 s of the XX century, when under the influence of the beginning of the process of globalization, transnational cooperation began to form, which actively entered the national markets of the countries of the world using FDI. The current study reviews the literature in the field of factors influencing the attraction of FDI. This goal has necessitated the formulation of the following tasks: to investigate the basic theoretical and empirical research; determine the directions of the influence of FDI on the economy of the state; literature research on the side effects of FDI. The main research methods are bibliographic analysis, critical analysis of scientific approaches solving FDI problems, retrospective analysis of literary sources. Most of the scientific literature focuses on the study of individual factors in attracting FDI to the economy of host countries. Simultaneously, the scientific discussion continues among foreign and domestic scientists regarding the formation of an optimal set of factors to stimulate the growth of the inflow of FDI in the economy of the recipient country. According to the results of the study, the author noted the presence of many problematic issues that require further study.
\end{abstract}

Keywords: FDI, globalization, factors, investment attraction, Spillover effects

\section{Introduction}

The study of FDI and its identification as a specific type of investment activity begins in the 60s of the XX century, when under the influence of the onset of globalization of the world economy, transnational corporations began to form, which actively enters the national markets of the world using FDI. Before '60s of XX century, FDI is considered a simple physical movement of capital in the framework of world trade. Heckscher (1949), Ohlin (1933), Nurkse (1953) suppoered this approach.

The first scientists to single out FDI as a specific type of investment activity are Hymer (1960), Kindlberg (1969). These scholars argue that FDI is a necessary condition for the firm to enter foreign markets and to win the competition through the capitalization of its specific competitive advantages.Further studies of FDI, conducted by scientists such as Vernon (1966), Caves (1971), Rugman (1980) focused on the implementation of FDI at the micro-level. Simultaneously, the intensification of globalization processes and the research for ways to enhance the growth of economies of developing countries lead to a gradual shift in emphasis from an individual enterprise (micro-level) to a country or the global economy as a whole (macro-level). In this context, it is necessary to note the scientific research of Kojima and Ozawa (1984) as well as Dunning (1993).

The processes of transformation and globalization of the world economy at the end of the XX century and in the first decade of the XXI century, associated with the emergence of a significant number of new states and their activation in the framework of building a market economy: the study of FDI at the micro-level (enterprise, business combination); the study of FDI at the macro-level (state) in the context of their attraction; the study of FDI at the macro-level (state) in terms of their impact on the national economy. Simultaneously, note that foreign scientists focus on all three areas of the FDI study, paying particular attention to the problem of attracting FDI by developing countries, including Russia. The following works have been singled out: Fabry and Zezhni (2006), Mohamed, Bruno, and Henrique (2010), Tintin (2013), Makoni (2014), Gokalpa and Eldirim (2016), Henrique (2010).

Regarding Russian scientists the problem of FDI has been developed by the domestic scientific community in 
the context of the transformation of the national economy into a market- type economy and has been particularly developed in 2000 year, when the country is in urgent need of investments, first as part of the active growth of the economy, and then as the main tool for dealing with the economic crisis and boosting the growth of the Russian economic system in the post crisis period. The following areas of FDI research in Russia can be distinguished: identifying the problems of FDI attraction; study and classification of factors attracting FDI into the country; identification of problems attracting FDI in Russian regions; the study of FDI effects on national and regional economies; the study of FDI Spillover effects.

Malin (2005) in his scientific study examines the organizational and economic problems of attracting FDI in the real sector of the economy. Simultaneously, the scientist considers the place and role of FDI at this stage of market transformations in Russia, identify the economic problems of intensifying investment activity in the real sector of the economy based on foreign capital on the example of the Russian Federation; form guidelines for improving the management organization and the system of stimulating FDI with an emphasis on the Russian economy.

A separate area of research by Russian scientists is to analyze the main factors and conditions for attracting FDI. For example Reshaev (2007) in his dissertation research focuses on the problems of stimulating the attraction of FDI in the Russian economy. The author discloses the theoretical aspects of stimulating the attraction of FDI; studies the investment climate of the Russian Federation; analyzing the dynamics of attracting FDI in the Russian economy; analyzing world experience in stimulating the attraction and regulation of FDI; offers directions for improving methods for attracting FDI in the Russian economy. Also, researchers, such as Sinyakova and Kvashina are researching the attraction of FDI into the country`s economy. In particular, Sinyakova (2009) considers possible mechanisms for attracting foreign capital into the Russian economy with a focus on FDI, paying particular attention to the relationship between FDI and the competitiveness of the Russian economy. The following aspects are revealed in scientific research: studies the relationship and mutual influence of FDI as well as the competitiveness of the country's economy in the context of globalization; assesses the role of Russia in the global economy as a capital- importer; identify prospects for attracting FDI in the context of increasing the competitiveness of the Russian economy.

Kvashnina (2015) studies the FDI influx in Russia under the economic sanctions against the country. At the same time the attention is paid to the following problems: assessing the dynamics of changes in the size of investments, including FDI in the period before and after the imposition of sanctions; identifying problems and negative factors affecting the FDI influx in the Russian economy; consideration of mechanisms for debt and equity financing of Russian companies in the Chinese market, as well as prospects for developing investment cooperation with Eastern partners.

It is also necessary to highlight such a direction of research in the field of FDI such as determination of the strategic directions of attraction and regulation of FDI. Nasybulina (2008) focuses on the disclosure of the following issues: the study of theoretical prerequisites for regulating FDI; disclosing the mechanism for regulating investment flows as a tool for attracting FDI into the economy of the Russian Federation; searching for ways to optimize the process of regulating FDI in the Russian economy.

The current study reviews the literature on the factors influencing the attraction of FDI.

This goal made it necessary to set the following tasks:

- explore basic theoretical and empirical research;

- to determine the directions of the influence of FDI on the economy of the state;

- research of the literature on the side effects of FDI.

\section{Method}

The main research methods are bibliographic analysis, retrospective analysis of literary sources and critical analysis of scientific approaches to solving FDI problems.

\section{Results}

The existing theoretical approaches and research directions in the field of FDI are considered and empirical studies and studies aimed at assessing the impact of the environment on attracting FDI to the country's economy.

\subsection{Theoretical Research}

Let us consider research devoted to the study of the influence of factors on attracting FDI.

Galenkova (2018) based on the study of foreign experience and empirical research of foreign scientists regarding 
the identification of factors influencing FDI attraction in the economy of developing countries emphasizes that institutional factors are the key to attracting FDI to the national economy. Based on the use of panel regression with fixed effects, the two-step least-squares method with instrumental variables is developed and proposed an appropriate model for estimating the FDI inflows into countries developing their own economic systems. The model is based on the institutional factors of the influence of FDI on the state economy. In turn, Brainard (1997) suggests that the key factors influencing the FDI attraction are the size of the donor country and the recipient country, as well as the distance between the countries, which allows him to propose to use the recipient of the gravity model to calculate the volume of FDI inflows into the country. This model is based on the GDP size of the donor country and the recipient country and the ratio of the indicator characterizing the size of the countries (investor and recipient of investments) using a distance between them as an indicator. The gravitational approach is a widely used tool for studying the relationship between the level of a country's development and the volume of attracted FDI. For example, Drapkin et al. (2015), relying on the gravitational approach to assess the influence of factors on attracting FDI in the national economy, using a gravitational model for calculating the volume of exports and imports of FDI to Russia. Simultaneously, when modeling, the author proposes to additionally attribute such factors as the openness of the country's economy to the key factors of the gravitational approach for calculating the inflow of FDI into the economy of the state, to which foreign scientists refer to the size of the country and the distance between the donor country and recipient countries; the level of remuneration in the recipient country; resistance for the donor country and the recipient country; common language; the presence of colonial ties.

The next approach to the study and identification of the factors forming the investment attractiveness of countries is to conduct an analysis using indices. In particular, a group of researchers Gornaya, Ischuk, and Halilova (2017) based on a study of influence factors and the conditions for the formation of investment attractiveness of Eastern European countries, proposes using the investment attractiveness index to assess the influence of factors on the attraction of FDI in the economy of developing countries. To calculate the investment attractiveness index is developed a regression model, based on economic, political, legal and socio- cultural factors of attracting FDI.

Economic and mathematical modeling is also one of the most common methods for researching and isolating factors, detecting the types and directions of dependencies. The main analyzed publications are shown in Table 1 .

Table 1. Methodological approaches to the study and identification of factors of influence on the level of attracting FDI

Author The essence of the research approach

Mehlis K.A. (2015) A model for calculating the potential volume of FDI outflows from developing countries, where she focuses on FDI influencing factors, such as the current average annual volume of FDI outflows; GDP per capita in the donor country and the recipient country. The author recommends using the developed model to assess the FDI potential for developing countries and countries with economies in transition.

Dang M.A. (2016) The systematization of influence factors attracting FDI in developing countries using ASEAN countries as an example. Simultaneously, the author identifies external (integration and globalization, political and natural disasters), as well as internal (economic, labor and natural resources, an open economy, etc.) factors influencing the level and size of attracting FDI to countries that are developing their own economic systems.

Fedorova E.A. (2014) Studying the factors affecting the influx of FDI in the regions of the Russian Federation.Moreover, the authors, based on the use of the linear regression model, identify the following main factors determining the FDI in the country`s regions: the proportion of unprofitable organizations; budget expenditures on social policy; the degree of depreciation of fixed assets; volume of innovative works; graduate specialists with higher education; the number of people engaged in scientific R\&D; volume of products shipped by type of economic activity.

Shkurupii O.V (2012) Factors of influence on attracting FDI into three groups: supply factors; demand factors; political factors. Simultaneously, in his research, the scientist does not distinguish between the factors of attracting FDI into the economy of the state and into individual enterprises in need of investment.

Prokhorova M.E. and Propose dividing factors influencing the attraction of FDI into macro and micro factors. Simultaneously, Gadiyak A.G. (2012) according to them, macrofactors should include: political, investment objects, the geographical location of the recipient country, natural conditions in the recipient country, production costs, logistics, inflation, market size, market growth, taxation, the potential of the recipient country, legal conditions. The micro-factors should include market segment, the financial position of the enterprise being the object of investment, depreciation of fixed assets, training level, the level of commodity production. 


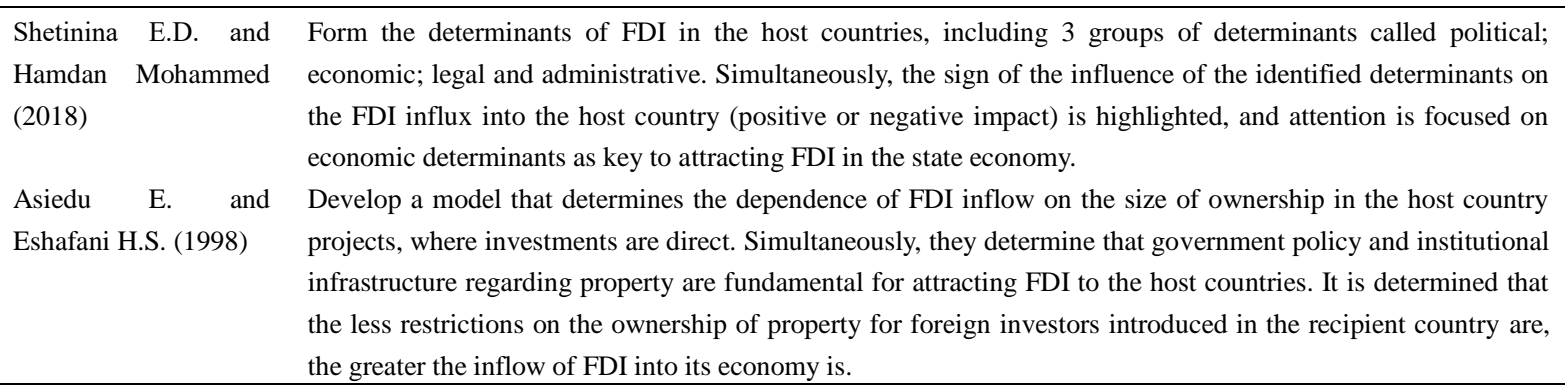

A separate area of research is the analysis of FDI for consistency and existence in a globalized economy. For example, Rud (2008), as part of his research, studies FDI attraction in Russia in the context of the global economy. Simultaneously, he focuses on studying the globalization of the world economy and its impact on FDI; critically examine conceptual and theoretical approaches to FDI study; highlight the influence factors on attracting FDI by the example of the Russian Federation in the context of accelerating globalization.

Baz and Milner (2008) approach the determination of factors influencing the FDI attraction in host countries in terms of the participation of such countries in international organizations, primarily the WTO, as well as intergovernmental organizations. The authors emphasize that the negotiation of attracting FDI to the recipient country based on membership in relevant international organizations, primarily trade, reduces investment risks, both for the donor and for the host country.

Thus, summarizing, we can conclude that the theoretical and methodological studies are mainly aimed at studying the influence and highlighting the main factors that affect the level and volume of attracted FDI.

\subsection{Empirical Research}

Most empirical studies in the field of FDI are aimed at studying a sample of countries with different levels of economic development.

So, Ozler et al. (1996), relying on empirical studies in 113 countries of the world in the period from 1950 to 1982 , investigate the relationship between political instability, GDP growth per capita and the inflow of FDI. Scientists note that during the functioning of the recipient country, which can be characterized as a period of political instability, the growth of GDP per capita, as well as the inflow of FDI, is less than during periods of stability of the political system of the host country.

The results of a study of 51 countries by Schneider and Frey (1985) showed that high inflation rates for investors are a signal of significant problems in the host country's economy and indicate significant risks for their investments. A similar study was conducted by Bilawal et al. (2014) regarding the impact of exchange rate changes on FDI flows to Pakistan between 1982 and 2013. The study found a significant positive relationship between the exchange rate and FDI.

The next group of studies was the study of the influence of the economic factors shown in Table 2.

Table 2. Empirical research on FDI

\begin{tabular}{|c|c|}
\hline Author & The essence of the research approach \\
\hline Lusgina A. (2016) & $\begin{array}{l}\text { Empirical data on attracting FDI to Belarus, Georgia and the Visegrad countries (Hungary, Poland, the Czech } \\
\text { Republic and Slovakia) note that internal factors generated primarily by state institutions of power are of key } \\
\text { importance for increasing the inflow of FDI to the recipient country, as well as formed under the influence of } \\
\text { the development of the national economic system }\end{array}$ \\
\hline $\begin{array}{l}\text { Nesterova D.V. and } \\
\text { Mariev O.S. (2005) }\end{array}$ & $\begin{array}{l}\text { Statistical data of attracting FDI in different regions of the Russian Federation conducted their ranking. As the } \\
\text { main factors are identified: economic indicators, infrastructure development, institutional development of the } \\
\text { region, regional economic policy, foreign economic openness, geographical location. }\end{array}$ \\
\hline $\begin{array}{l}\text { Dudareva A.B., } \\
\text { Polyakova } \quad \text { A.A., } \\
\text { Sidorin A.A. (2017) }\end{array}$ & $\begin{array}{l}\text { Statistical data on the dynamics and structure of FDI in the Russian economy in } 2010-2015 \text {, as well as the } \\
\text { place of the Russian Federation in the world ranking in terms of FDI and GDP, revealed factors of a negative } \\
\text { impact on the inflow of FDI into the country's economy }\end{array}$ \\
\hline Ason T.A. (2018) & $\begin{array}{l}\text { Empirical research on FDI in the Russian Federation characterizes the factors determining the current state of } \\
\text { FDI inflows to Russia, and identifies factors that inhibit the inflow of such investments into the country. }\end{array}$ \\
\hline
\end{tabular}


Tretyak N.N. (2013) Data on FDI in Ukraine between 2010 - 2017 years, form a list of factors influencing their influx into the country, which includes the following: organizational, legal, political, economic, country potential, financial, social and cultural, international relations, economic development, general economic conditions. Separately, the factors of negative influence on the attraction of FDI in the country's economy are highlighted.

Gorbunova M. Ln, Research the features of FDI financing in the regions of the Russian Federation by Chinese business entities. Ovchinikova $\quad$ V., The authors test a series of hypotheses using the methods of parametric and nonparametric statistics. Based on Apykhtina A. Yu the obtained results, the following main conclusions are devised: when choosing the location of their capital, (2016) Chinese investors are not guided by factors such as consumer potential and the growth rate of the domestic market, as well as the availability of a raw material component in the economy of the Russian Federation. There is no connection between the number of migrants from China arriving in the region and the volume of FDI from China. A significant negative relationship is revealed between the territorial remoteness of the region from China and the volume of investments from the People`s Republic of China.

Buchanan B., Lee., Analysis of data from 164 countries around the world from 1996 to 2006 study the influence of the institutional Rishi M. (2012) environment of the state on the FDI inflows level. Based on the study, scientists conclude that the effective development of institutions in the country is essential and has a positive effect on the influx of FDI into recipient countries.

\subsection{Directions of FDI Influence on the State Economy.}

Studying the factors influencing the attraction of FDI in the state economy, it is necessary to understand their relationship with the effects of FDI on the national economic system. What combination of factors stimulating the influx of such investments the state will choose the result for its economy will be, as well as all its entities without exception, including state and municipal authorities, business units and households. Thus, we can argue that the consideration of the factors attracting FDI into the country's economy is not advisable without studying the existing and potential impact of such investments on its development, which requires the consideration of the scientific developments of domestic and foreign scientists on this problem.

Bandurka and Nosova (2016) conduct an analysis of current trends in the relationship and mutual influence of FDI and economic growth. Consider the external and internal effects from FDI on technology transfer and import in the manufacturing sector. Investigate the areas of investment activities of global TNCs, including contract operations. Analyze the factors stimulating economic growth. Clark, Hihgfill, Campino, and Rehman (2011) in their scientific study examines the impacts of FDI on economic growth in host countries developing their own economic systems. Based on the research, scientists conclude that FDI is associated with positive technological Spillover effects, economic growth, and growing income inequality in recipient countries. Simultaneously, the authors indicate that there are enough studies in the scientific literature that refute their conclusions, which makes the author's development controversial.

Eton and Kortum (2001) pay attention to the FDI influence on the economy of the recipient country through the diffusion of acquired technologies, which contributes to their wider use in the process of exchange of ideas. Also, FDI, according to scientists, has a positive effect on labor productivity of the labor force involved in the conduct of R\&D. Based on what, a conclusion about the FDI-positive impact increasing the level of welfare in the recipient country is drawn. Petrikova (2009) based on studies of the dynamics of GDP and FDI in Russia for 2001-2009 year, identifies the FDI relationship with the final use of GDP and offers a set of indicators for quantifying the contribution of FDI to GDP growth, as well as indicators of the macroeconomic efficiency of FDI in the recipient country.

Nosova (2011) indicates that FDI stimulates the growth of gross savings in the country, which, in the short term leads to a quantitative increase in production volumes, and in the long term to an increase in the capital-labor ratio and output.

Ovchinnikova (2004) in her dissertation focuses on the economic and mathematical modeling of the FDI impact on economic growth in developing countries. Simultaneously, the author studies the main approaches to the economic analysis of FDI, classifies the determinants of FDI, studies the construction of optimization models for the impact of FDI on economic growth in developing countries and conducts an econometric modeling of the contribution of FDI to economic growth in developing countries.

Markovskaya and Anoshkina (2016) analyze the differences in the impact of FDI on the economic growth of developed and developing countries. To build a model of the dependence of GDP on FDI is used panel data from the observation of 10 developed countries for the period from 1983 to 2013 years and 11 developing countries for the period from 1994 to 2013 years. Scientists conclude that developing countries gain less effect from FDI 
due to the nontransparent institutional environment and the negative impact of other non-economic factors.

Borenstein, De Gregorio, and Lee (1998) study the FDI impact on economic growth as part of an intercountry regression using data of FDI inflows from developed countries to 69 developing countries over the past two decades. Scientists conclude that FDI is an important means of technology transfer and contribute more to the growth of the national economy of the recipient country than domestic investments. However, higher FDI productivity persists only when the host country has a minimum threshold stock of human capital. In addition, such investments increase total investment in the economy of the host country by more than $100 \%$, which indicates the predominance of the effects of complementarity with firms from the recipient-country.

Melnyk, Kubatko, and Pysarenko (2014) examine the FDI impact on economic growth in post-communist economies in Europe.Simultaneously, scientists conduct a theoretical analysis of the impact of FDI on economic growth at the level of the state economy; examine in detail the Spillover effects from attracting FDI to the national economy; form a theoretical model of the relationship of state economic growth and the volume of FDI attraction; conduct empirical analysis of 26 countries with economies in transition from Central and Eastern Europe over a period of 13 years to identify key aspects of the FDI influence on the economic growth of selected states.

Rogatnev (2015) in his dissertation considers the effects of FDI attraction in developing countries. The author pays special attention to the disclosure of theoretical and methodological aspects of the study of the socio-economic effects of FDI in developing countries; the formation of a generalized model of the effects of direct investment and the disclosure of its theoretical capabilities; identifying the negative effects of the activities of international corporations in developing countries and the possibility of minimizing them; disclosure of the positive effects of the activities of international corporations in developing countries and the possibility of maximizing them; the formation of directions of state regulation of the effects of direct foreign investment on the economic development of developing countries.

Summarizing the study of foreign literature sources, we can identify three key points of view regarding the impact of FDI on host countries (mainly developing) in the context of studying the factors attracting FDI to the state's economy, namely,

1). The positive, neutral or negative impact of FDI on the economic growth of the host country, developing its own economic system. Highlighting the scientific work of Mansfield and Romeo (1980); Haddad and Harrison (1993); Lipsy (2002).

2). The positive impact of FDI on the level of technological and innovative development of host regions and countries. Focus on the scientific research of the following scientists: Findlay (1978); Rappaporta (2000); De Grigorio (2005).

3). The positive, neutral or negative impact of FDI on exports and imports of host countries (mainly developing). We note the scientific developments of: Barry and Bradley (1997);Goldberg and Kleina (1999); Kutana and Vuksic (2008).

A study of the factors influencing the attraction of FDI in the state economy, as well as their relationship with the development of host countries, requires the study of the Spillover effects. Noting the importance of such effects for the economy of the recipient country, we focus on the key importance of Spillover effects for host countries developing their own economic systems.

A study of literary sources makes it possible to highlight the work of foreign scientists regarding the study of Spillover effects from attracting FDI into the economies of host countries, mainly those that develop their own national economies. We single out the works of Katurii (2000); Gerga and Strobla (2001); Liu (2002); Zhirma (2002); JDamiyana et al. (2003); Batry, Morisset, and Saggy (2003); Yavorchik (2004); PBuckley et al. (2007); Stanchika (2007); Tian et al. (2011).

Against the background of foreign studies on the Spillover effects from attracting FDI in the economies of recipient countries, it is necessary to highlight the work of Russian scientists researching such effects mainly in relation to the Russian economy. We single out the work of Yudaeva et al. (2003); Kadochnikova et al. (2011); Fedorova and Barikhina (2015); Fedorova, Korkmazova and Muratova (2016); Ivanova (2017); Fedorova, Nikolaev, Nikolaeva, and Alekseeva (2018).

\section{Discussion}

Studies of the factors influencing the attraction of FDI in the economy of the state began in the in the 60s of the $\mathrm{XX}$ century along with the beginning of the processes of globalization and the emergence of transnational 
corporations. Scientific research in the framework of studying the factors of attracting FDI to the economic system of the countries of the world received special development at the end of the 20th and the beginning of the 21 st century, when the emphasis of scientists shifted to the consideration of such factors in relation to developing countries that compete for investment resources in international capital markets. Simultaneously, studies of the factors influencing the growth of FDI in the economy of recipient states began to be accompanied by studies of the influence of such investments on the economic systems of host countries, considering the Spillover effects.

Most of the scientific literature focuses on the study of individual factors in attracting FDI to the economy of host countries. Simultaneously, the scientific discussion continues among foreign and domestic scientists regarding the formation of an optimal set of factors to stimulate the growth of the inflow of foreign direct investment in the economy of the recipient country. We note the presence of many problematic issues that require further study, namely:

1). The formation of a clear classification of factors influencing the attraction of FDI to the economy of the state with the provision of characteristics of such factors.

2). Substantiation of the optimal set of factors of influence on attracting foreign direct investment in the economy of developed and developing countries.

3). Development of a model for assessing the impact of a complex of factors on attracting FDI into the economic system of the state, considering the peculiarities of the country's development.

4). Revealing the relationship between the factors of attracting foreign direct investment in the country's economy and the influence of FDI on its development.

5). Development of a model of the influence of foreign direct investment on the economy of the state, considering the Spillover effects and a set of factors used to attract FDI.

Thus, summarizing, we can conclude that the theoretical and methodological studies are mainly aimed at studying the influence and highlighting the main factors that affect the level and volume of attracted foreign direct investment by using economic and mathematical tools.

\section{References}

Amal, M., Tomio, B., Raboch, H. (2010). Determinants of Foreign Direct Investment in Latin America. GCG Georgetown University-UNIVERSIA, 4(3), 116-133.

Asiedu, E., \& Esfahani, H. S. (1998). Ownership Structure in Foreign Direct Investment Projects. Department of Economics, University of Illinois, 1998. Retrieved from http://www2.ku.edu/ kuwpaper/Archive/papers/Pre1999/wp1998_3.pdf

Azzimonti, M., \& Sarte, P. (2007). Barriers to Foreign Direct Investment Under Political Instability. Economic Quarterly, 93(3), 287-315.

Batra, G., Morisset, J., \& Saggi, K. (2003). Vertical Linkages between Multinationals and Domestic Suppliers: Whom Do Tey Beneft and Why? World Bank Working Paper, 44, 1-30.

Bilawal, M., Ibrahim, M., Abbas, A., ... Tehreem, F. (2014). Impact of Exchange Rate on Foreign Direct Investment in Pakistan. Advances in Economics and Business, 2(6), 223-231.

Borensztein, E., De Gregorio, J., \& Lee, J. W. (1998). How Does Foreign Direct Investment Affect Economic Growth? Journal of International Economics, 45, 115-135. https://doi.org/10.1016/S0022-1996(97)00033-0

Brainard, S. L. (1997). An Empirical Assessment of the Proximity Concentration Tradeoff between Multinational Sales and Trade. American Economic Review, 87(4), 520-544.

Buchanan, B. G., Le, Q. V., \& Rishi, M. (2012). Foreign direct investment and institutional quality: Some empirical evidence. International Review of Financial Analysis, 21, 81-89. https://doi.org/10.1016/j.irfa.2011.10.001

Buckley, P. J., Clegg, J., \& Wang, C. (2007). Is the relationship between inward FDI and spillover effects linear? An empirical examination of the case of China. Journal of International Business Studies, 38(3), 447-59. https://doi.org/10.1057/palgrave.jibs.8400274

Busse, M., Hefeker, C., \& Nelgen, S. (2013). Foreign Direct Investment and Exchange Rate Regimes. Economics Bulletin, 33(1), 843-858.

Buthe, T., \& Milner, H. (2008). The Politics of Foreign Direct Investment into Developing Countries: Increasing FDI through International Trade Agreements. American Journal of Political Science, 52(4), 741-762. 
https://doi.org/10.1111/j.1540-5907.2008.00340.x

Clark, D. P., Hihgfill, J., De, O., Campino, J., \& Rehman, S. S. (2011). FDI, technology spillovers, growth, and income inequality: A selective survey. Global Economy Journal, 11(2), 1-44. https://doi.org/10.2202/1524-5861.1773

Damijan, J. P., Knell, M., Majcen, B., \& Rojec, M. (2003). Technology Transfer through FDI in Top-10 Transition Countries: How Important are Direct Effects, Horizontal and Vertical Spillovers? WDI Working Paper, 549, 31. https://doi.org/10.2139/ssrn.404241

Dunning, J. H. (1993). Multinational Enterprises and the Global Economy. Wokingham: Addison-Wesley.

Eaton, J., \& Kortum, S. (2001). Technology, trade and growth: A unified framework. European Economic Review, 4-6(45), 1-17. https://doi.org/10.1016/S0014-2921(01)00129-5

Fabry, N., \& Zeghni, S. (2006). How former communist countries of Europe may attract inward foreign direct investment? A matter of institutions, Communist and Post-Communist Studies, 39, 201-219. https://doi.org/10.1016/j.postcomstud.2006.03.006

Fan, J. P. H. (2009). Institutions and Foreign Direct Investment: China versus the Rest of the World. World Development, 37(4), 852-865. https://doi.org/10.1016/j.worlddev.2008.07.016

Girma, S. (2002). Geographic Proximity, Absorptive Capacity and Productivity Spillovers from FDI: A Treshold Regression Analysis. GEP Research Paper, University of Nottingham. Retrieved from https://ideas.repec.org/p/eeg/euroeg/25.html

Gokalp, M. F., \& Yildirim, A. (2016). Institutions and Economic Performance: A Review on the Developing Countries. Procedia Economics and Finance, (38), 347-359. https://doi.org/10.1016/S2212-5671(16)30207-6

Görg, H., \& Strobl, E. (2001). Multinational companies and productivity spillovers: A meta-analysis with a test for publication bias. The Economic Journal, 111(475), 723-739. https://doi.org/10.1111/1468-0297.00669

Heckscher, E. (2007). International Trade, and Economic History. In F. Ronald, R. G. H. Henriksson, H. Lindgren, and M. Lundahl (Eds.). The MIT Press.

Hymer, S. (1976). The International Operations of National Firms: A Study of Direct Foreign Investment. Cambridge: The MIT Press.

Javorcik, B. (2004). Does foreign direct investment increase the productivity of domestic firms? In search of spillovers through backward linkages. American Economic Review, 94(3), 605-627. https://doi.org/10.1257/0002828041464605

Kathuria, V. (2000). Productivity spillovers from technology transfer to Indian manufacturing firms. Journal of International Development, 343-369. https://doi.org/10.1002/(SICI)1099-1328(200004)12:3<343::AID-JID639>3.0.CO;2-R

Kindleberger, C. (1969). American Business Abroad. The International Executive, 11(2), 11-12. https://doi.org/10.1002/tie.5060110207

Koboekae, T. (2012). The impact of political risk on foreign direct investment decisions by South African multinational corporations. University of Pretoria. Retrieved from https://repository.up.ac.za/handle/2263/30613

Kojima, K., \& Ozawa, T. (1984). Micro- and Macro-Economic Model of Direct Foreign Investment: Toward a Synthesis. Hitotsubashi Journal of Economics, 26(2), 135-145.

Liu, Z. (2002). FDI and technology spillovers: Evidence from China. Journal of Comparative Economics, 30(3), 579-602. https://doi.org/10.1006/jcec.2002.1789

Makoni, P. L. (2014). Factors influencing the attraction of foreign direct investment and foreign portfolio investment into African economies. Corporate Ownership \& Control, 11(4), 203-213. https://doi.org/10.22495/cocv11i4c1p5

Maza, A., \& Villaverde, J. (2015). The determinants of inward foreign direct investment: Evidence from the European region. International Business Review, 24, 209-223. https://doi.org/10.1016/j.ibusrev.2014.07.008

Melnyk, L., Kubatko, O., \& Pysarenko, S. (2014). The impact of foreign direct investment on economic growth: Case of post communism transition economies. Problems and Perspectives in Management, 12(1), 17-24. 
Mohamed, A., Bruno, T., \& Henrique, R. (2010). Determinants of Foreign Direct Investment in Latin America. CGC Georgetown University, 4(3), 116-133.

Nurkse, R. (1953). Problems of Capital Formation in Underdeveloped Countries. Oxford: Basil Blackwell.

Ohlin, B. G. (1933). Interregional and international trade. Cambridge: Harvard University Press.

Rugman, A. M. (1980). Internalization as a general theory of foreign direct investment: A re-appraisal of the literature. Weltwirtschaftliches Archiv, 116(2), 365-379. https://doi.org/10.1007/BF02696864

Senkuku, A. M., \& Gharleghi, B. (2015). Factors influencing foreign direct investment inflow in Tanzania. International Journal of Business and Management, 7(10), 48-56. https://doi.org/10.5539/ijbm.v10n7p48

Stančík, J. (2007). Horizontal and Vertical FDI Spillovers: Recent Evidence from the Czech Republic. CERGE-EI Working Paper, 340. https://doi.org/10.2139/ssrn.1093662

Tian, X., Lo, V., Lin, S., \& Song, S. (2011). Cross-region FDI productivity spillovers in transition economies: Evidence from China. Post-Communist Economies, 23(1), 105-118. https://doi.org/10.1080/14631377.2011.546979

Tintin, C. (2013). The determinants of foreign direct investment inflows in the Central and Eastern European Countries: Teimportance of institutions. Communist and Post-Communist Studies, 46, 287-298. https://doi.org/10.1016/j.postcomstud.2013.03.006

Tobin, J., \& Rose-Ackerman, S. (2005). Foreign Direct Investment and the Business Environment in Developing Countries: The Impact of Bilateral Investment Treaties. https://doi.org/10.2139/ssrn.557121

Vernon, R. (1966). International Investment and International Trade in the Product Cycle. II Quarterly Journal of Economics, 80(C), 190-207. https://doi.org/10.2307/1880689

Yudaeva, K., Kozlov, K., Malentieva, N., \& Ponomareva, N. (2003). Does foreign ownership matter? The Russian experience. Economics of Transition, 11(3), 383-409. https://doi.org/10.1111/1468-0351.00157

Асон, Т. А. (2018). Перспективы привлечения прямых иностранных инвестиций в российскую экономику. Вектор экономики, 4, 24-40.

Бандурка, А. М., Носова, О. В., \& Носова, Т. Ю. (2016). Взаимовлияние прямых иностранных инвестиций и экономического роста. Европейские Перспективы, 1, 5-13.

Под ред, О. В. (2012). Внешнеэкономическая деятельность предприятия: Учебное пособие. Шкурупий, Киев, Центр учебной литературы.

Галенкова, А. Д., Мариев, О. С., \& Чукавина, К. В. (2018). Эконометрическое моделирование притока прямых иностранных инвестиций в развивающиеся страны. Журнал Экономической Теории, 2(18), 345-349. https://doi.org/10.31063/2073-6517/2018.15-2.19

Гоблик, В. В., \& Феер, А. Е. (2016). Детерминанты притока прямых иностранных инвестиций в развивающиеся страны, Новое слово в науке: Перспективы развития: материалы VII Междунар. науч.-практ. конф. (Чебоксары, 15 янв. 2016 г.). В 2 т. Т. 2 / редкол.: О.Н. Широков [и др.], Чебоксары: ЦНС «Интерактив плюс», pp. 225-227.

Горбунова, М. Л., Овчинников, В. Н., \& Апыхтина, А. Ю. (2016). Анализ китайских прямых инвестиций в субъекты Российской Федерации, Вестник Нижегородского университета им. НИ Лобачевского, Серия: Социальные Науки, 1(41), 16-21.

Горбунова, О. А. (2018). Привлечение прямых иностранных инвестиций в российскую экономику в условиях действия санкций. Российское Предпринимательство, $8(19), \quad$ 2185-2200. https://doi.org/10.18334/rp.19.8.39261

Данг, М. А. (2016). Пути и методы активизации привлечения прямых иностранных инвестиций в странах АСЕАН в условиях глобализаџии (на примере СРВ), Диссертаџия на соискание учёной степени кандидата экономических наук. Москва: Федеральное государственное бюджетное образовательное учреждение высшего образования «Государственный университет управления».

Демченко, А. Г. (2011). Проблемы привлечения иностранных инвестиций в экономику Республики Беларусь. Retrieved from http://elib.bsu.by/bitstream/123456789/94295/1/218-223\%202_67.pdf.

Драпкин, И. М., Мариев, О. С., \& Чукавина, К. В. (2015). Количественная оценка потенциала импорта и экспорта прямых зарубежных инвестиций в российской экономике на основе гравитационного подхода. Журнал Новой Экономической Ассоииации, 4(28), 75-95. 
Дударева, А. Б., \& Полякова, А. А. (2017). Сидорин А.А., Проблемы финансирования инвестиционных процессов с использованием зарубежного капитала. Russian Journal of Agricultural and Socio-Economic Sciences, 3(63), 45-52.

Кадочников, С. М., Драпкин, И. М., Давидсон, Н. Б., \& Федюнина, А. А. (2011). Эффективность национальных компаний и диверсификация промышленности региона как факторы внешних эффектов от прямых зарубежных инвестиций в российской экономике. Российский Журнал Менеджмента, 9(2), 3-26.

Кашкарева, Е. А. (2007). Влияние прямых иностранных инвестиций на рост российской экономики, Диссертация на соискание учёной степени кандидата экономических наук. Красноярск: Федеральное государственное образовательное учреждение высшего профессионального образования «Сибирский Федеральный Университет».

Квашнина, И. А. (2015). Приток капитала в Россию в условиях санкций. Российский Внешнеэкономический Вестник, 11, 3-12.

Корицкий, А. В. (2014). Иностранные инвестиции и человеческий капитал. Вестник НГУЭУ, 1, 58-63.

Лузгина, А. (2016). Национальные особенности и международный опыт привлечения прямых иностранных инвестиций. Банковский Вестник, Июнь, 21-29.

Малин, Д. В. (2005). Организачионно-экономические проблемы привлечения прямых иностранных инвестиций в реальный сектор экономики, Диссертация на соискание учёной степени кандидата экономических наук. Москва: Государственный университет управления.

Марковская, Е. И., \& Аношкина, Е. С. (2016). Анализ влияния прямых иностранных инвестиций на экономический рост в развитых и развивающихся странах, Научно-технические ведомости Санкт-Петербургского государственного политехнического университета. Экономические Науки, 6(256), 21-30.

Мехлис, К. А. (2015). Основные тенденщии взаимного прямого иностранного инвестирования между Российской Федерачией и странами Европейского Союза, Диссертаџия на соискание учёной степени кандидата экономических наук. Москва: Московский государственный университет им. М.В. Ломоносова.

Муха, Д. (2015). Влияние привлечения прямых иностранных инвестиций на внешнюю торговлю и платежный баланс Беларуси. Банковский Вестник, 2, 35-45.

Насыбулина, В. П. (2008). Стратегические направления привлечения и регулирования прямых иностранных инвестиций в экономику России, Диссертаџия на соискание ученой степени кандидата экономических наук. Краснодар: Государственное образовательное учреждение высшего профессионального образования Кубанский государственный университет.

Нестерова, Д. В., \& Мариев, О. С. (2005). Факторы привлечения прямых иностранных инвестиций в российские регионы. Экономика Региона, 4, 57-70.

Овчинникова, Н. В. (2004). Экономико-математическое моделирование влияния прямых иностранных инвестиций на экономический рост в развивающихся странах, Диссертация на соискание учёной степени кандидата экономических наук. Москва: Московский государственный университет.

Петрикова, Е. М. (2009). Прямые иностранные инвестиции и экономический рост. Вопросы Статистики: Научно-Информачионный Журнал, 9, 14-21.

Прохорова, М. Е., \& Гадияк, А. Г. (2012). Факторы влияния на прямые иностранные инвестиции. Научный Вестник Института Международных Отношений НАУ, 1-2(1), 6-11.

Решаев, П. Л. (2007). Стимулирование привлечения прямых иностранных инвестиций в экономику России, Диссертация на соискание учёной степени кандидата экономических наук. Москва: ГОУ ВПО «Российская экономическая академия имени В.Г. Плеханова».

Рогатнев, Н. С. (2015). Эффекты прямых иностранных инвестищий в развивающиихся странах: типология, моделирование, регулирование, Диссертация на соискание учёной степени кандидата экономических наук. Воронеж: Федеральное государственное бюджетное образовательное учреждение высшего профессионального образования «Воронежский государственный университет».

Рудь, Н. Ю. (2008). Привлечение прямых иностранных инвестиций в Россию в условиях глобальной экономики, Диссертация на соискание учёной степени доктора экономических наук. Москва: 
Всероссийская академия внешней торговли.

Скрипникова, Г. В., \& Постаногова, М. С. (2015). Прямые иностранные инвестиции в России: тенденции и проблемы их привлечения. Интернет-журнал Науковедение, 4(29), 1-9.

Третяк, Н. Н. (2013). Факторы формирования инвестиционного климата в Украине. Финансовый Простор, $3,165-170$.

Федорова, Е. А., \& Барихина, Ю. (2015). Оценка горизонтальных и вертикальных спилловер-эффектов от прямых иностранных инвестиций в России. Вопросы Экономики, 3, 5-21.

Федорова, Е. А., Коркмазова, Б. К., \& Муратов, М. А. (2016). Спилловер-эффекты в российской экономике: региональная специфика. Экономика Региона, 1(12), 139-149.

Федорова, Е. А., Николаев, А. Э., Николаева, А. С., \& Алексеева, М. А. (2018). Оценка влияния прямых иностранных инвестиций на экономику России в период санкций на основе Спилловер-эффектов. Пространственная Экономика, 1, 37-58. https://doi.org/10.14530/se.2018.1.037-058

Федорова, Е. А. (2014). Факторы, влияющие на приток иностранных инвестиций в регионы. Региональная Экономика: Теория И Практика, 43(370), 51-61.

Щетинина, Е. Д., \& Хамдан, М. (2018). Детерминанты прямых иностранных инвестиций в принимающих странах - ситуация Сирии. Вестник Белгородского Государственного Технологического $\begin{array}{lllll}\text { Университета им. В.Г. Шухова, } & \text { 144-155. }\end{array}$ https://doi.org/10.12737/article_5af5a7353de584.18814479

\section{Copyrights}

Copyright for this article is retained by the author(s), with first publication rights granted to the journal.

This is an open-access article distributed under the terms and conditions of the Creative Commons Attribution license (http://creativecommons.org/licenses/by/4.0/). 